\title{
The base of the Toarcian (Early Jurassic) in the Almonacid de la Cuba section (Spain). Ammonite biostratigraphy, magnetostratigraphy and isotope stratigraphy
}

\footnotetext{
${ }^{1}$ Departamento-UEI de Paleontología, UCM - CSIC. José Antonio Novais, 2, 28040 Madrid, Spain; E-mail: mjcomas@geo.ucm.es; angoy@geo.ucm.es

${ }^{2}$ Departamento de Estratigrafía-UEI de Correlaciones, UCM - CSIC. José Antonio Novais, 2, 28040 Madrid, Spain; E-mail: jgomez@geo.ucm.es ${ }^{3}$ Departamento de Física de la Tierra I. Avenida Complutense s/n, Universidad Complutense, 28040 Madrid, Spain; E-mail: mlosete@fis.ucm.es, ali@fis.ucm.es
}

The Almonacid de la Cuba section, located in the Iberian Range, in central-eastern Spain, contains an outstanding record of the Pliensbachian-Toarcian boundary (Early Jurassic). Four ammonite assemblages, characterized respectively by the presence of Pleuroceras, Canavaria, Dactylioceras (Eodactylites) and Dactylioceras (Orthodactylites) have been distinguished. The base of the Toarcian is located at level CU35.2, based on the first occurrence of Dactylioceras. The presence of Boreal and Mediterranean taxa allows correlation between both bioprovinces. Magnetostratigraphy shows the most complete record of reversals of the Earth magnetic field for the base of Toarcian. The onset of the positive $\delta^{13} C$ excursion which has been found in the Toarcian of several sections in Europe has been recorded. Average paleotemperatures for the latest Pliensbachian Spinatum Zone was about $12.5^{\circ}$. Seawater temperature rise during the lowermost Toarcian, reaching average temperatures of $16.7^{\circ} \mathrm{C}$ at the Tenuicostatum Zone. The ${ }^{87} \mathrm{Sr} /{ }^{86} \mathrm{Sr}$ curve fits with the LOWESS calibration curve.

\section{Introduction}

The Almonacid de la Cuba section, located in the Iberian Range of central-eastern Spain (Fig.1), shows a good representative record for the Pliensbachian-Toarcian boundary under outstanding outcrop conditions. The succession has been previously described by Sequeiros et al. (1978), Comas-Rengifo (1982), Comas-Rengifo and Goy (1997), Comas-Rengifo et al. $(1999,2010)$ and proposed as a complementary section of the Toarcian global stratotype (Goy et al., 2006).
The current official candidate for designation as the Global Stratotype Section and Point (GSSP) for the base of the Toarcian Stage is the Peniche section, located in western Portugal (Elmi et al., 1996; Elmi, 2004, 2006; Hesselbo et al., 2007). However, no magnetostratigraphic scale has been constructed in the potential stratotype. Stable isotope curves in the Peniche section have been acquired from bulk carbonates (Duarte, 1998; Hesselbo et al., 2007), from brachiopods (Suan et al., 2008), and $\delta^{13} \mathrm{C}$ and ${ }^{87} \mathrm{Sr} /{ }^{86} \mathrm{Sr}$ from belemnite carbonates (Hesselbo et al., 2007). However, $\delta^{18} \mathrm{O}$ curves have been obtained from brachiopods and the resolution of the record of paleotemperature variations based on $\delta^{18} \mathrm{O}$ proxies across the Pliensbachian-Toarcian is low (Suan et al., 2008).

Here we present the biostratigraphy, lithostratigraphy, sedimentology, sequence stratigraphy, magnetostratigraphy and isotope stratigraphy of the Almonacid de la Cuba section which contains a continuous record of the Pliensbachian-Toarcian boundary. Results are compared with other European and American sections and discussed.

\section{Material and methods}

The Almonacid de la Cuba section has been studied bed by bed, collected ammonites were classified and belemnites prepared for isotopic studies. The natural gamma ray of the sediments was measured with a portable scintillation counter.

The magnetostratigraphic sampling was carried out using a gasoline-powered drilling machine. A magnetic compass and an inclinometer were used for sample orientation. A total of 57 oriented cores were collected for the magnetostratigraphic study. To perform field test, an additional site (18 samples) with a different structural tilt was studied (ACI site, Fig.1b). The structure sampled is not a single cylindrical fold, therefore the only-inclination fold-test was performed. Magnetic analyses of specimens were carried out in the Paleomagnetic Laboratories of the ETH in Zürich and Madrid. The natural remanent magnetisation (NRM) of the samples was measured 


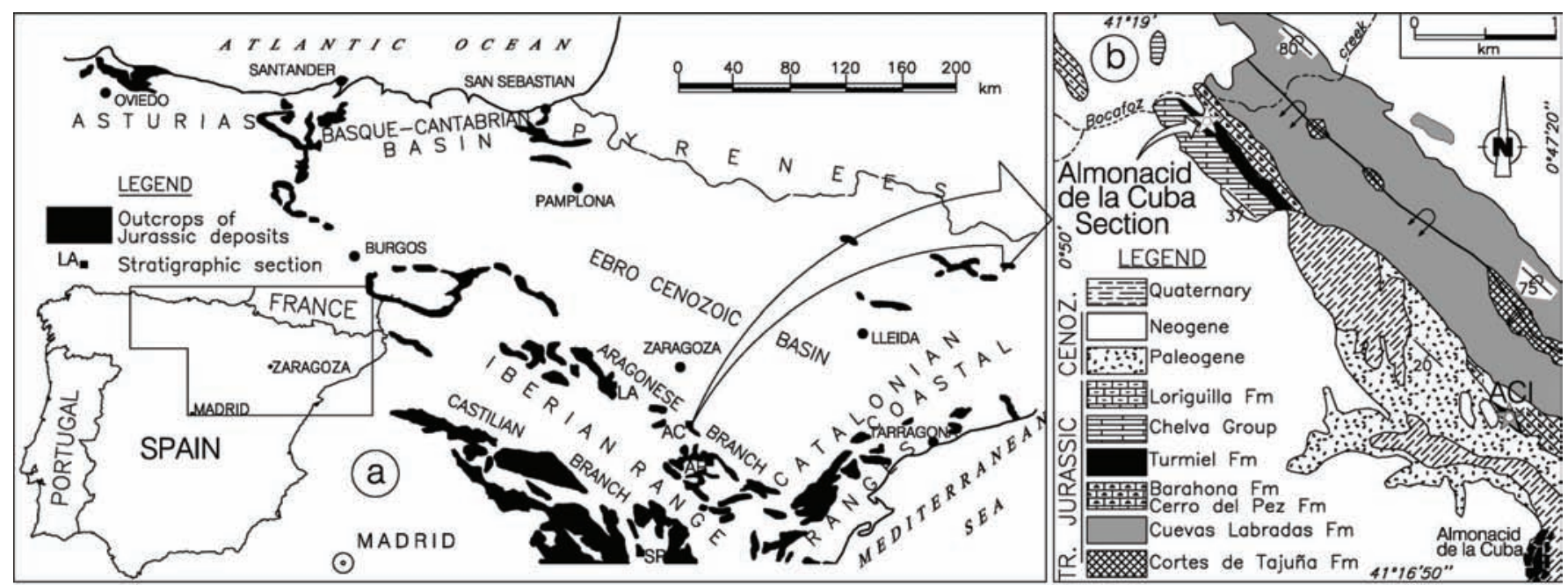

Figure 1. Location maps of the Almonacid de la Cuba section. a - Outcrops of the Jurassic deposits in central and northern Spain. Sections mentioned in the text: LA - La Almunia. AC - Almonacid de la Cuba. AR - Ariño. SP - Sierra Palomera. b - Geological map of the Almonacid de la Cuba area (after Ruiz, Lendínez and Gabaldón, 1986, modified) showing the position of the studied section. ACI - Additional site sampled for the paleomagnetic fold test. The Cerro del Pez and the Barahona Fms have been grouped in the geological map due to scale constrictions.

using a three-axis 2G-Enterprise cryogenic and a JR5 spinner magnetometers. Stepwise acquisition of isothermal remanent magnetization (IRM) followed by isothermal remagnetisation in three orthogonal directions and subsequent progressive thermal demagnetisation was carried out in order to identify the magnetic mineralogy of the samples. The field applied along the three orthogonal axes was: $2 \mathrm{~T}, 0.4 \mathrm{~T}$ and $0.12 \mathrm{~T}$.

To obtain the primary seawater stable and strontium isotope signal, a total of 40 belemnite rostra were collected and analysed. The rostra were studied on polished samples and thick sections under the petrographic and cathodoluminescence microscope. The potentially unaltered non-luminescent portions of the rostra were sampled using a microscope-mounted dental drill. Stable isotopes analyses were performed in the Michigan University (USA) labs. In all samples, isotope ratios are reported in per mil with respect to the standard Peedee belemnite (PDB). A total of 15 diagenetically screened belemnite calcite were analyzed for strontium isotope in the Laboratory of Geochronology and Isotopic Geochemistry of the Universidad Complutense of Madrid.

\section{Lithostratigraphy, sedimentology and sequence stratigraphy}

Two lithostratigraphical units can be recognized in the Almonacid de la Cuba section: the upper part of the Barahona Fm, which is composed of bioclastic wackestone-packstone limestone with interbedded marls, and the lower part of the Turmiel Fm which is constituted by an alternation of lime mudstones and marls, except on its lowermost part, where the limestones are bioclastic lime wackestones. The Pliensbachian-Toarcian boundary is located within the deposits of the Turmiel Fm (Fig.2). The Barahona Fm was deposited in an internal shallow, well-oxygenated carbonate platform on which oysters (Gryphaea) predominated, but remains of nektic organisms, such as ammonites and belemnites, are rare (Gómez and Goy, 2005). Deposition of the Turmiel Fm at Almonacid de la Cuba took place in a low-energy, normal salinity, open-marine external platform environment. The hemipelagic facies of the Turmiel Fm in the Almonacid de la Cuba section were deposited in the downthrown block of a syndepositional fault, where expanded sections with no significant discontinuities and containing ammonites and belemnites, were deposited (Goy et al., 1997; Gómez and Goy, 2005).

The Upper Pliensbachian deposits are organized in shallowingupward sequences characterized by thickening-upward carbonates, which are frequently topped by soft- to firm- grounds and occasionally by hard-grounds with ferruginous crusts. The Pliensbachian-Toarcian boundary is located within one of these shallowing-upward sequences, where no indications of significant stratigraphic gaps were found. The set of shallowing-upward sequences containing the Pliensbachian-Toarcian boundary, which corresponds to the LJ3-1 cycle for Central and Northern Spain (Gómez and Goy, 2005), is interrupted by an ephemeral transgressive interval that occurred in the lower Tenuicostatum Zone. However, the shallowing-upward sequences continue up to the top of level 64, where a new transgressive episode corresponding to cycle LJ3-2 starts. The "Toarcian transgression" developed in a few pulses, reaching the transgressive peak at the Middle Toarcian Bifrons Zone, as it was observed in many other areas of Spain (Gómez and Goy, 2000, 2005).

\section{Ammonite record and biostratigraphy}

The ammonite assemblages of both the Spinatum and the Tenuicostatum zones are well represented in the Almonacid de la Cuba section. The studied time interval is characterized by the occurrence of Pleuroceras, Canavaria, Dactylioceras (Eodactylites) and $D$. (Orthodactylites). The latest subgenus also occurs in younger beds. A similar succession was recognized in the Peniche section of Portugal (Mouterde, 1955; Elmi, 2004, 2006), and in northwestern Algeria (Elmi et al., 2006).

Spinatum Zone (Upper Pliensbachian). The ammonite assemblages of the Upper Pliensbachian Spinatum Zone (at least 


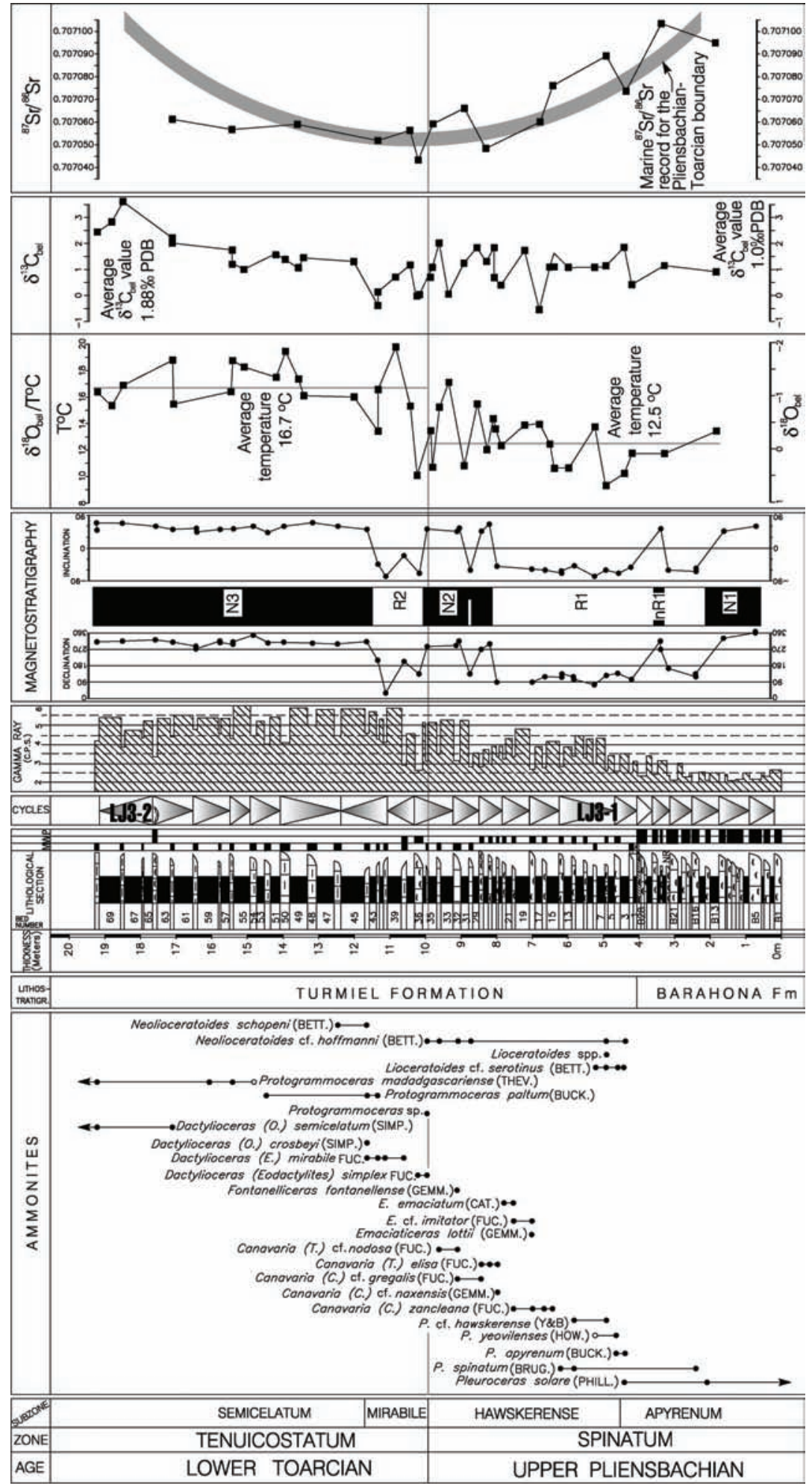

Figure 2. Almonacid de la Cuba stratigraphic column showing the ammonites distribution, the lithological succession, facies cycles, gamma-ray curve, magnetostratigraphic chart, stable isotope,${ }^{87} \mathrm{Sr} /{ }^{86} \mathrm{Sr}$ curves and biozonation. Seawater palaeotemperatures, indicated at the upper part of the curve, have been calculated from the $\delta^{18} \mathrm{O}_{\text {bel }}$ values. Comparison of average paleotemperatures recorded during the uppermost Pliensbachian and the average paleotemperatures recorded at the Lower Toarcian vary between $12.5^{\circ} \mathrm{C}$ and $16.7^{\circ} \mathrm{C}$ (grey lines), marking the end of the Late Pliensbachian cooling and the onset of the Early Toarcian warming intervals. The ${ }^{87} \mathrm{Sr} /{ }^{86} \mathrm{Sr}$ data are in a good agreement with data shown in the LOWESS calibration curve of McArthur and Howarth (2004), shown in grey.
$10.16 \mathrm{~m}$ thick) are characterized by the presence of Pleuroceras and Canavaria. Other genera are Emaciaticeras, Fontanelliceras, Lioceratoides and Neolioceratoides. The Spinatum Zone has been subdivided into a lower Apyrenum Subzone and an upper Hawskerense Subzone (Dean et al., 1961; Dommergues et al., 1997; Page, 2003; Meister et al., 2006).

The $4.98 \mathrm{~m}$ thick Apyrenum Subzone is characterized by the occurrence of Amaltheidae, particularly of the genus Pleuroceras (P. solare, $P$. spinatum, $P$. apyrenum and $P$. yeovilense). Hildoceratidae (Harpoceratinae) of the genera Lioceratoides (L. cf. serotinus) and Neolioceratoides (N. cf. hoffmanni) also occur.

In the Hawskerense Subzone, the Amaltheidae are recorded together with the last occurrences of Hildoceratidae (Harpoceratinae). Between beds CU16 and CU34, the Pleuroceras are replaced by Hildoceratidae (Hildoceratinae) of the genus Emaciaticeras, Canavaria and locally, Fontanelliceras. This subzone, which is $5.18 \mathrm{~m}$ thick, is characterized by Pleuroceras ( $P$. spinatum, $P$. cf. yeovilense, $P$. hawskerense). The Pleuroceras occur together with Lioceratoides ( $L$. cf. serotinus) and Neolioceratoides ( $N$. cf. hoffmanni), as well as Canavaria $[C .(C$.$) zancleana, C .(C$.) cf. gregalis, C. (T.) elisa, and C. (T.) cf. nodosa]. In the lower part of its stratigraphic range, the genus Pleuroceras occurs together with Emaciaticeras (E. lottii, E. cf. imitator, E. emaciatum) whereas in the upper part, it occurs with Fontanelliceras ( $F$. fontanellense) and Neolioceratoides ( $N$. hoffmanni). In summary, the assemblages of the lower part of this subzone are dominated by the amaltheids (i.e. Pleuroceras), whereas in some levels of the upper part the Arieticeratinae became the only constituent of the ammonite assemblage. No Arieticeratinae were found, the Harpoceratinae are less than the $10 \%$ of the total, and the Harpoceratinae are always present but in a low proportion.

Tenuicostatum Zone (Lower Toarcian). The Lower Toarcian Tenuicostatum Zone has been marked by the first appearance datum of the genus Dactylioceras, used here for recognition of the base of the Toarcian. The assemblage is characterized by species of the subgenera Dactylioceras (Eodactylites) and Dactylioceras (Orthodactylites) which characterize the Mirabile and the Semicelatum subzones, respectively. The stratigraphic range of the Tenuicostatum Zone in the Iberian Range coincides with the Polymorphum Zone in the Betic Cordillera, and with the Semicelatum Zone in Portugal (Mouterde, 1967; Comas-Rengifo and Goy, 1978; Goy et al., 1988; Elmi et al., 1989, 1994, 1997).

The $1.57 \mathrm{~m}$ thick Mirabile Subzone is characterized by species of the subgenus Dactylioceras (Eodactylites) such as D. (E.) simplex and D. (E) 
mirabile, which correspond to the Simplex and Mirabile horizons proposed by Goy et al. (1988). In some levels, Neolioceratoides ( $N$. hoffmanni, N. schopeni) and Protogrammoceras (P. paltum) also cooccur.

The Semicelatum Subzone (10.37 m thick) is characterized by the presence of several species of the subgenus Dactylioceras (Orthodactylites). The presence of $D$. (O.) crosbeyi characterizes the Crosbeyi Horizon of Goy and Martínez (1990), which is equivalent to the Clevelandicum Subzone defined by Howarth (1973). The species $D$. (O.) ernsti and $D$. (O.) semicelatum characterize the Semicelatum Horizon (Goy and Martínez, 1990), which is equivalent to the Semicelatum Subzone (Howarth, 1973).

In summary, the assemblages of the Tenuicostatum Zone are dominated by Dactylioceratidae, whereas Harpoceratinae are less than $30 \%$. Other groups, such as Bouleiceratinae documented in neighbour areas, have not been identified in the Almonacid de la Cuba section. Higher in the succession, Cleviceras exaratum and Hildaites murleyi which are generally used for characterization of the Serpentinus Zone, co-occur. In younger levels of the same area, Harpoceras $(H$. serpentinus and other species) appear.

\section{Magnetostratigraphy}

A complex magnetization behaviour has been observed in the Almonacid de la Cuba section. Details of the palaeomagnetic study can be found in Palencia-Ortas (2004) and Comas-Rengifo et al. (2010). Natural Remanent Magnetization (NRM) intensity ranged from $510^{-3} \mathrm{~A} / \mathrm{m}$ to $610^{-5} \mathrm{~A} / \mathrm{m}$. Two or three magnetization components were found. Isothermal Remanent Magnetization (IRM) acquisition experiments indicate the presence of high coercitivity minerals, since saturation is not reached at $2 \mathrm{~T}$, and low coercitivity minerals as well. Thermal demagnetization of three IRM orthogonal components corroborate that high coercitivity minerals carry most of the IRM in two phases: one with maximum unblocking temperature around $150^{\circ} \mathrm{C}$ indicating the presence of goethite and other with maximum unblocking temperature around $700^{\circ} \mathrm{C}$ indicating the presence of hematite. In addition to these high coercitivity minerals, some samples show the presence of a low coercitivity phase with maximum unblocking temperatures of $575-600^{\circ} \mathrm{C}$ indicating the presence of magnetite. The ChRM was isolated by thermal cleaning after the $450^{\circ}$ heating step. Normal and reversed polarities were found. Maximum unblocking temperatures of about $680^{\circ} \mathrm{C}$ indicate that the hematite is the ChRM carrier.

The ChRM passed the reversal test (McFadden and McElhinny, 1990) at the 95\% and 99\% significance level (transitional directions were excluded). Reversal test is of "B" type $\left(5^{\circ}<\Upsilon_{c}<10^{\circ}\right)$, both at $95 \%$ and $99 \%$ confidence level. This means that the ChRM component was correctly isolated.

An additional site (AC1 in Fig.1b) was sampled to perform a fold-test (McFadden and Jones, 1981). The best grouping of ChRM directions was observed after tilt correction, but the fold-test was not statistically significant at the $95 \%$ level of confidence. We consider that it was due to structural problems since inclinations tend to converge after bedding correction, but not declinations. A fold-test with only inclinations values using the McFadden and Reid (1982) method has been performed. The inclination fold-test was positive at the $99 \%$ confidence level. This guaranties that the ChRM is primary in origin and acquired in early Jurassic times.
A magnetic polarity column for the Pliensbachian-Toarcian boundary at the Almonacid de la Cuba section has been constructed on the basis of the polarities of the ChRM (Fig.2). Three normal and two reversed polarity magnetozones have been identified. Named N13 and R1-2. Within R1 magnetozone, a smaller magneto-subzone has been identified and labeled nR1. Polarity identified by only one sample is marked by a discontinuous bar.

At the bottom of the column, the N1 magnetozone is observed within the Pliensbachian Apyrenum Subzone. R1 is a long magnetozone extending up to the upper Hawskerense Subzone. The small magnetosubzone $\mathrm{nR} 1$ is located near the top of the Barahona Fm. The end of the Hawskerense Subzone is characterized by a normal polarity (N2 magnetozone). R2 nearly coincides with the boundaries of the Mirabile Subzone and the lower boundary of the Toarcian. N3 is a long magnetozone which characterizes the Tenuicostatum Zone, starting in the upper part of the Mirabile Subzone and extending up to the top of the section (Semicelatum Subzone).

\section{Isotope stratigraphy and palaeotemperatures}

The presence of belemnites in virtually all the studied beds allowed obtaining excellent $\delta^{13} \mathrm{C}-\delta^{18} \mathrm{O}$ and ${ }^{87} \mathrm{Sr} /{ }^{86} \mathrm{Sr}$ curves based on diagenetically screened belemnite calcite (Fig.2).

Stable isotope record. The $\delta^{13} \mathrm{C}_{\mathrm{bel}}$ record shows values ranging from -0.52 to $3.59 \%$ PDB. These values tend to be quite uniform at within the uppermost Pliensbachian, averaging 1\%o PDB, but they tend to increase at the Lower Toarcian, where average values of $1.88 \%$ PDB were reached. The increase in the $\delta^{13} \mathrm{C}_{\text {bel }}$ values marks the onset of a positive excursion which has been recorded in most European sections, whether in bulk rock or belemnite carbonates, in marine organic matter, and in wood (e.g. Jenkyns and Clayton, 1997; Schouten et al., 2000; McArthur et al., 2000; Hesselbo et al., 2007; Gómez et al., 2008).

In the $\delta^{18} \mathrm{O}_{\text {bel }}$ curve, which shows values ranging from $0.73 \%$ to $-1.71 \%$ PDB, also significant changes at the Pliensbachian-Toarcian transition are observed. At the Spinatum Zone, the $\delta^{18} \mathrm{O}_{\text {bel }}$ values were slightly negative $(-0.29 \%$ o PDB in average), but around the transition between both stages, an excursion towards more negative values, averaging $-1.3 \%$ o PDB, is recorded. This negative $\delta^{18} \mathrm{O}_{\text {bel }}$ shift has also been reported in many European sections such as the Whitby and the Yorkshire areas in the UK (Sælen et al., 1996; Jenkyns, 2003), in the French Paris Basin (Dera et al., 2009), in the Peniche section in Portugal (Suan et al., 2008), in Bulgaria (Metodiev and KolevaRekalova, 2008), in Northern Spain, in the Basque-Cantabrian Basin (Rosales et al., 2004), Asturias (Gómez et al., 2008), and in Central Spain (Gómez et al., 2008).

Seawater palaeotemperatures. The obtained $\delta^{18} \mathrm{O}_{\text {bel }}$ values have been used as a proxy for calculation of the seawater palaeotemperatures at the Pliensbachian-Toarcian transition, using the Anderson and Arthur (1983) equation.

The temperature variations during the Late PliensbachianEarly Toarcian are shown in Fig.2. At the uppermost Pliensbachian Spinatum Zone, the paleotemperatures were relatively low, from $9.2^{\circ} \mathrm{C}$ recorded around the Apyrenum-Hawskerense zonal boundary, up to $17^{\circ} \mathrm{C}$ calculated for one sample located near the Pliensbachian- 
Toarcian boundary. Average paleotemperature of $12.5^{\circ} \mathrm{C}$ calculated for the Late Pliensbachian notably increased during the Early Toarcian, where average calculated temperatures were $16.7^{\circ} \mathrm{C}$, including peak values above $19.5^{\circ} \mathrm{C}$, reached at the Mirabile and the Semicelatum subzones.

${ }^{87} \mathrm{Sr} /{ }^{86} \mathrm{Sr}$ curve. Plots of obtained ${ }^{87} \mathrm{Sr} /{ }^{86} \mathrm{Sr}$ values against the stratigraphic column are displayed in Fig.2. The highest values (0.707104) are recorded at the uppermost Pliensbachian Apyrenum Zone. These values gradually fall towards values lower than 0.707050 around the Pliensbachian - Toarcian boundary, shifting towards higher values in the Lower Toarcian, where values of 0.707062 are reached in the belemnite calcite sampled in the Semicelatum Subzone.

\section{Discussion and conclusions}

The Almonacid de la Cuba section contains an excellent record of the Pliensbachian-Toarcian boundary, where no indications of major sedimentary breaks have been found. Four ammonite assemblages, characterized respectively by the presence of Pleuroceras, Canavaria, Dactylioceras (Eodactylites) and Dactylioceras (Orthodactylites) have been distinguished. The base of the Toarcian is located at level CU35.2, based on the first occurrence of Dactylioceras.

The Spinatum Zone is characterized by the succession of Pleuroceras ( $P$. transiens - $P$. solare - $P$. cf. hawskerense), which are also used as zonal marker in NW Europe (Howarth, 1958; ComasRengifo, 1982; Dommergues et al., 1997; Meister et al., 2006). However, the assemblages of the upper part of the Spinatum Zone at Almonacid de la Cuba can also be compared with the ammonite zonation proposed for Southern Europe, on which the use of the Emaciatum Zone, subdivided into the Solare and the Elisa subzones, is preferred (Braga et al., 1982, 1984; Braga, 1983; Macchioni, 2002; Meister et al., 2006). Beds containing $P$. hawskerense are correlated with the Hawskerense Subzone of the NW European province (Dommergues et al., 1997; Page, 2003; Meister et al., 2006). Levels with Emaciaticeras and Canavaria can be correlated with the Elisa Subzone of the Emaciatum Zone, described by Braga (1983) in the Betic Cordillera (Southern Spain), and also documented in the Mediterranean area by Macchioni and Cecca (2002), Macchioni and Meister (2003), Page (2003) and Meister et al. (2006).

The ammonite assemblages of the Tenuicostatum Zone mainly contain taxa characteristic of the NW Europe province such as Protogrammoceras paltum and Dactylioceras (Orthodactylites) with predominance of Dactylioceratidae over Harpoceratinae. However, taxa of the Mediterranean province, such as Neolioceratoides, Dactylioceras (Eodactylites) and P. madagascariense are only recognized in a few levels. In the Mirabile Subzone, $D$. (Eodactylites) co-occurs with $P$. paltum. The occurrence of taxa from both provinces in the Almonacid de la Cuba section is useful to improve the correlation between the NW European and the Mediterranean provinces

Two paleobiogeographic features can be highlighted: (1) the occurrence of $D$. (E.) simplex allows correlation with the level 15E of the Peniche section, as well as with some North African and South American sections (Elmi et al., 1974, 2006; Hillebrandt and SchmidtEffing, 1981); (2) P. paltum is a good marker for correlation with the NW European and the Mediterranean provinces. In the Ricla section (Iberian Range, Spain), Peniche section (Lusitanian Basin, Portugal) and the Mellala section (Traras Mountains, Algeria), this species, or a similar form, occurs at the base of the Mirabile Subzone (Goy and Martínez, 1990; Elmi, 2004; Bécaud, 2006; Elmi et al., 2006). Also Macchioni (2002) found that P. paltum is common at the Mirabile Horizon in the Mediterranean area.

Referring magnetostratigraphy, N3 is a clear magnetozone observed at the Iznalloz section (Betic Cordillera, southern Spain) by Galbrun et al. (1990) and recently described at the Sierra Palomera and Ariño sections (Iberian Range, Central Spain) by Osete et al. (2007). R2 magnetozone is also in agreement with the reversed polarity observed in the lower part of the Iznalloz section. R2 and R1 were also recorded in the Breggia section (Horner and Heller, 1983), but the N2 magnetozone was not detected in the Alpine section. Probably because the Lower Toarcian is only poorly represented in Breggia (the Tenuicostatum Zone is around $30 \mathrm{~cm}$ thick, Horner and Heller, 1983). According with data presented here, it seems that there is a gap at the Pliensbachian-Toarcian boundary in the Alpine section.

The Magnetic Polarity Time Scale (MPTS) proposed by Ogg $(1995,2004)$ was mostly based on the Breggia section, consequently, is consistent with the general pattern of our data, but the N2 magnetozone is absent, and the age control of lower Toarcian reversals is poor. The new MPTS proposed by Osete et al. (2007) for the Toarcian is in agreement with the new data presented here, but it does not extend bellow the Toarcian. The magnetostratigraphic study of the Neuquén section (Iglesia-Llanos and Riccardi, 2000) has not enough resolution to describe in detail the reversals of the earth magnetic field for this time period. Therefore the magnetostratigraphic data presented here are the most complete record of reversals of the earth magnetic field for the Pliensbachian-Toarcian boundary.

A good record of the onset of the positive $\delta^{13} \mathrm{C}$ excursion reported in many European sections has been obtained in the Almonacid de la Cuba section. Most authors are in agreement about the interpretation of the Early Toarcian positive excursion as the response of water masses to excess and rapid burial of large amounts of organic carbon rich in ${ }^{12} \mathrm{C}$, that led to enrichment in ${ }^{13} \mathrm{C}$ of the sediments (Jenkyns and Clayton 1997; Schouten et al., 2000), or to removal from oceans of large amounts of isotopically light carbon as organic matter into black shales or methane hydrates, which leaves oceanic carbon isotopically heavy (McArthur et al., 2000). Data presented in this work show a good latest Pliensbachian-earliest Toarcian $\delta^{18} \mathrm{O}_{\text {bel }}$-based paleotemperature curve (Fig. 2). Average palaeotemperatures measured in the latest Pliensbachian Spinatum Biochron of about $12.5^{\circ} \mathrm{C}$ are in good agreement with average temperatures of $11.6^{\circ} \mathrm{C}$ calculated in Asturias (Northern Spain, Gómez et al., 2008) and of $12^{\circ} \mathrm{C}$ in the Basque-Cantabrian Basin (also in Northern Spain, Rosales et al., 2004). These temperatures can be considered low for a calculated Central Spain palaeolatitude of about $35^{\circ} \mathrm{N}$ during the PliensbachianToarcian (Osete et al., in press). Similar values of oceanic paleotemperatures recorded in the UK and in Germany (Bailey et al., 2003) confirm that the latest Pliensbachian and the earliest Toarcian represent a relative cooling interval.

A marked increase of the seawater temperature started during the Toarcian. At the Tenuicostatum Zone average temperatures of $16.7^{\circ} \mathrm{C}$ in the Almonacid de la Cuba section, $15^{\circ} \mathrm{C}$ in the Asturias sections, in Northern Spain and $16^{\circ} \mathrm{C}$ in the La Almunia-Ricla section, located in the Iberian Range, near the studied section, were reached (Gómez et al., 2008). That represents a $\Delta T$ between 4 and $5^{\circ} \mathrm{C}$ around the Pliensbachian-Toarcian transition. This palaeotemperature rise is probably one of the main causes of the so-called upper Pliensbachian 
biotic crises, and clearly marks the onset of the outstanding Early Toarcian warming interval which accelerates around the Tenuicostatum - Serpentinum zonal boundary in many European sections and extensively develops during the Early and Middle Toarcian (McArthur et al., 2000; Jenkyns, 2003; Rosales et al., 2004; Gómez et al., 2008).

The ${ }^{87} \mathrm{Sr} /{ }^{86} \mathrm{Sr}$ values obtained in the Almonacid de la Cuba section fully agree with the previously published data (McArthur et al., 2000, 2001; McArthur and Howarth, 2004; Hesselbo et al., 2007). Upper Pliensbachian ${ }^{87} \mathrm{Sr} /{ }^{86} \mathrm{Sr}$ values generally decrease at the Hawskerense Zone, reaching a first minimum value below 0.707050 in the upper portion of this Zone and a slight increase in the uppermost portion of this Zone. Minimum values are recorded at the base of the Toarcian, as predicted by the LOWESS calibration curves, and ${ }^{87} \mathrm{Sr} /{ }^{86} \mathrm{Sr}$ slowly recovers along the Tenuicostatum Zone. These results strongly support the reliability of the available ${ }^{87} \mathrm{Sr} /{ }^{86} \mathrm{Sr}$ values and the good geochemical signal included in the belemnite calcite of this section.

\section{Acknowledgements}

This research work was financed by projects CGL2008-01273, CGL2008-02203 and CGL2008-03112/BTE of the Spanish Ministerio de Educación. We acknowledge Prof. F. Heller for his valuable advice and to the group of paleomagnetism of the Institut für Geophysik (ETH Zurich) for the use of the paleomagnetic laboratory, as well as Prof. G. Pavia and M.H. Enriques, who provided useful criticism and valuable suggestions for the improvement of the manuscript. Authors dedicated this work to the memory of Prof. S. Elmi (+) and kindly acknowledge his comments and interesting suggestions on the Almonacid de la Cuba section.

\section{References}

Anderson, T.F., Arthur, M.A., 1983, Stable isotopes of oxygen and carbon and their application to sedimentologic and paleoenvironmental problems, in Arthur, M. A., Anderson, T. F., Kaplan, I. R., Veizer, J., and Land, L. S., eds., Stable Isotopes in Sedimentary Geology, SEPM Short Course, vol. 10, pp. 1 - 151. Tulsa.

Bailey, T. R., Rosenthal, Y., McArthur J. M., van de Schootbrugge, B., and Thirlwall, M. F., 2003, Paleoceanographic changes of the Late Pliensbachian Early Toarcian interval: a possible link to the genesis of an Oceanic Anoxic event: Earth and Planetary Science Letters, v. 212, pp. 307 - 320.

Bécaud, M., 2006, Les Hildoceratidae (Ammonitina) du Toarcien de la bordure sud et sudest du Massif Armoricain (France): Documents des Laboratoires de Géologie Lyon, v. 162, pp. 1 245.

Braga, J. C., 1983, Ammonites del Domerense de la Zona Subbética (Cordilleras Béticas, S. de España): Tesis Doctoral, Universidad de Granada, Granada, 410 pp.

Braga, J. C., Comas-Rengifo, M. J., Goy A., and Rivas P., 1982, Comparaciones faunísticas y correlaciones en el Pliensbachiense de la Zona Subbética y Cordillera Ibérica: Boletín de la Real Sociedad Española de Historia Natural, Geología, v. 80, pp. 221 - 244.

Braga, J. C., Comas-Rengifo, M. J., Goy, A., and Rivas, P., 1984, The Pliensbachian of Spain. Ammonite succesion, boundaries and correlations, in Michelsen, O., and Zeiss, A., ed, I International Symposium on Jurassic Stratigraphy, Copenhagen, 1984, v. 1, pp. 160 - 176.

Comas-Rengifo, M. J., 1982, El Pliensbachiense de la Cordillera Ibérica: Tesis Doctoral, Facultad de Ciencias Geológicas, UCM. Colección Tesis Doctorales, UCM, v. 19/1985, pp. 1 - 591.

Comas-Rengifo, M. J., and Goy, A., 1997, Ammonoideos del tránsito Pliensbachiense-Toarciense en la sección de Almonacid de la Cuba (Sector Central de la Cordillera Ibérica, España), in Meléndez, G., and Pérez-Urresti, I., eds, Comunicaciones IV Congreso del Jurásico de España, Alcañiz, 1997, p. 55.

Comas-Rengifo, M. J., and Goy, A., 1978, El PliensbachienseToarciense en la Rambla del Salto (Sierra Palomera, Teruel): Dpto. Paleontología, Facultad de CC. Geológicas, Universidad Complutense de Madrid, pp. IV.1 - IV.11.

Comas-Rengifo, M. J., Arias, C., Gómez, J. J., Goy, A., Herrero, C., Osete, M. L., Palencia, A., 2010, A complementary section for the proposed Toarcian (Lower Jurassic) Global Stratotype: the Almonacid de la Cuba section (Spain): Stratrigraphy and Geological Correlations, in press.

Comas-Rengifo, M. J., Gómez, J. J., Goy, A., Herrero, C., Perilli, N., and Rodrigo, A., 1999, El Jurásico Inferior en la sección de Almonacid de la Cuba (Sector central de la Cordillera Ibérica, Zaragoza, España): Cuadernos de Geología Ibérica, v. 25, pp. 27 $-57$.

Dean, W. T., Donovan, D. T., and Howarth, M. K., 1961, The Liassic ammonite zones and subzones of the north-west European Province: Bulletin of the British Museum (Natural History), Geology Series, v. 4, pp. 435 - 505.

Dera, G., Pucéat, E., Pellenard, P., Neige, P., Delsate, D., Joachimski, M.M., Reisberg, L., and Martinez, M. 2009, Water mass exchange and variations in seawater temperature in the NW Tethys during the Early Jurassic: Evidence from neodymium and oxygen isotopes of fish teeth and belemnites: Earth and Planetary Science Letters, v. 286, pp. $198-207$.

Dommergues, J.-L., Meister, C., and Mouterde, R., 1997, 3. Pliensbachien, in Cariou, E., and Hantzpergue, P., coord, Biostratigraphie du Jurassique ouest-européen et méditerranéen: zonations parallèles et distribution des invertébrés et microfossiles: Bulletin du Centre Recherches Elf Exploration-Production, Mém. 17, pp. $15-23$.

Duarte, L. V., 1998, Clay minerals and geochemical evolution in the Toarcian - Lower Aalenian of the Lusitanian Basin (Portugal): Cuadernos de Geología Ibérica, v. 24, pp. 69 - 98.

Elmi, S., 2004, Early Jurassic carbonate evolution in the Lusitanian Bassin (Portugal): facies, sequence stratigraphy and cyclicity. Stop 6. Toarcian GSSP candidate: the Peniche section, in Duarte, L. V., and Henriques, M. H., eds., Carboniferous and Jurassic Carbonate Platforms of Iberia, 23nd IAS Meeting Sedimentology, Coimbra, 2004, Field Trip Guide Book v. I, pp. 64 - 67.

Elmi, S., 2006, Pliensbachian/Toarcian boundary: the proposed GSSP of Peniche (Portugal): Volumina Jurassica, v. 4, pp. 5 - 16.

Elmi, S., Atrops, F., and Mangold, C., 1974, Les zones d'ammonites du Domerien-Callovien. de l'Algérie Occidentale. $1^{\text {èr }}$ partie: Domerien-Toarcien: Documents des Laboratoires de Géologie Lyon, v, 61, pp. 3 - 83.

Elmi, S., Gabilly, J., Mouterde, R., Rulleua, L., and Rocha, R., 1994,. Lètage Toarcien de l'Europe et de la Téthys: divisions et corrélations: Geobios, Mémoire Spécial, v. 17, pp. 149-159.

Elmi, S., Goy, A., Mouterde, R., Rivas, P., and Rocha. R. B., 1989, Correlaciones bioestratigráficas en el Toarciense de la Península Ibérica: Cuadernos de Geología Ibérica, v. 13, pp. 265 - 277.

Elmi, S., Rulleau, L., Gabilly, J., and Mouterde, R., 1997, 4. Toarcian, in Cariou, E., and Hantzpergue, P., coord, Biostratigraphie du 
Jurassique ouest-européen et méditerranéen: zonations parallèles et distribution des invertébrés et microfossiles. Bulletin du Centre Recherches Elf Exploration-Production, Mém. 17, pp. 25 - 36.

Elmi, S., Marok, A., Sebane, A., and Almeras, Y., 2006, Importance of the Mellata section (Traras Mountains, NW Algeria) for the correlations of the Pliensbachian/Toarcian boundary: Volumina Jurassica, v. 4, pp. 158 - 160.

Fisher, R. A., 1953, Dispersion on a sphere: Proceedings of the Royal Society of London, v. A. 217, pp. 295 - 305.

Galbrun, B., Baudin, F., Fourcade, E., and Rivas, P., 1990, Magnetostratigraphy of the Toarcian Ammonitico Rosso limestone at Iznalloz, Spain: Geophysical Research Letters, v. 17, pp. 2441 $-2444$.

Gómez, J. J., and Goy, A., 2000, Sequential analysis of the Toarcian in the northern and central-eastern part of the Iberian subplate. Spain: GeoResearchForum, v. 6, pp. 301 - 309.

Gómez, J. J., and Goy, A., 2005, Late Triassic and Early Jurassic palaeogeographic evolution and depositional cycles of the Wetern Tethys Iberian platform system (Eastern Spain): Palaeogeography, Palaeoclimatology, Palaeoecology, v. 222, pp. 77 - 94.

Gómez, J. J., Goy, A., and Canales, M. L., 2008, Seawater temperature and carbon isotope variations in belemnites linked to mass extinction during the Toarcian (Early Jurassic) in Central and Northern Spain. Comparison with other European sections: Palaeogeography, Palaeoclimatology, Palaeoecology, v. 258, pp. $28-58$

Goy, A., Comas-Rengifo, M. J., Arias, C., García Joral, F., Gómez, J. J., Herrero, C., Martínez, G., and Rodrigo, A., 1997, El Tránsito Pliensbachiense/Toarciense en el sector central de la Rama Aragonesa de la Cordillera Ibérica (España): Cahiers de l'Institut Catholique de Lyon, v. 10, pp. 159 - 179.

Goy, A., Comas-Rengifo, M. J., Arias, C., Gómez, J. J., González, A., Herrero, C., Palencia, A., Perilli, N., and Rodrigo, A., 2006, The Pliensbachian/Toarcian boundary in the Almonacid de la Cuba section (Iberian Range, Spain): Volumina Jurasica, v. 4, pp. 164 -165 .

Goy, A., Jiménez, A., Martínez, G., and Rivas, P., 1988, Difficulties in correlating the Toarcian ammonite sucesión of the Iberian and Betics Cordilleras, in Rocha, R., and Soares, A. eds, $2^{\text {nd }}$ International Symposium on Jurassic Stratigraphy, Lisboa, 1988, pp. 155 - 178.

Goy, A, and Martínez, G., 1990, Biozonación del Toarciense en el área de La Almunia de Doña Godina-Ricla (Sector Central de la Cordillera Ibérica): Cuadernos de Geología Ibérica, v. 14, pp. 11 $-53$.

Hesselbo, S. P., Jenkyns, H. C., Duarte, L. V., and Oliveira, L. C. V., 2007, Carbon-isotope record of the Early Jurassic (Toarcian) Oceanic Anoxic Event from fossil wood and marine carbonate (Lusitanian Basin, Portugal): Earth and Planetary Science Letters, v. 253 , pp. $455-470$.

Hillebrandt, A., and Schmidt-Effing, R., 1981, Ammoniten aus dem Toarcium (Jura) von Chile (Sudamerika): Zitteliana, v. 6, pp. 3- 64.

Horner, F., and Heller, F., 1983, Lower Jurassic magnetostratigraphy at the Breggia Gorge (Ticino, Switzerland) and Alpe Turati (Como, Italy): Geophysical Journal of the Royal Astronomical Society, v. 73, pp. $705-718$.

Howarth, M. K, 1958, A monograph of the ammonite of the Liassic family Amaltheidae in Britain: Palaeontographical Society of London, v. 1958, part II, pp. xv-xxxvii, 27 - 53.

Howarth, M. K., 1973, The stratigraphy and ammonite fauna of the Upper Liassic grey shales of the Yorkshire coast: Bulletin of the British Museum (Natural History), Geology Series, v. 24, pp. 235 - 227.

Iglesia-Llanos, M. P., and Riccardi, A. C., 2000, The Neuquén composite section: magnetostratigraphy and bioestratigraphy of the marine lower Jurassic from the Neuquén basin (Argentina): Earth and Planetary Science Letters, v. 181, pp. 443 - 457.

Jenkyns, H .C., 2003, Evidence for rapid climate change in the Mesozoic-Palaeogene greenhouse world: Philosophical Transactions of the Royal Society of London, v. A 361, pp. 1885 - 1916.

Jenkyns, H. C., and Clayton, C. J., 1997, Lower Jurassic epicontinental carbonates and mudstones from England and Wales: chemostratigraphic signals and the early Toarcian anoxic event: Sedimentology, v. 44, pp. 687 - 706.

Macchioni, F., 2002, Myths and legends in the correlation between the Boreal and Tethyan Realms. Implications on the dating of the Early Toarcian mass extinctions and the Oceanic Anoxic Event: Geobios, Mémoire Spécial, v. 35, pp. 150 - 164.

Macchioni, F., and Cecca, F., 2002, Biodiversity and biogeography of middle-late Liassic ammonoids: implications for the early Toarcian mass extinction: Geobios, Mémoire Spécial, v. 35, pp. $165-175$.

Macchioni, F., and Meister, C., 2003, Ammonite biostratigraphy of some Mediterranean sections. 2: The succession of the Gola del F. Burano (Umbria-Machigiano Basin, Apennine), a reference section for Tethyan Domain: Revue de Paléobiologie Genéve, v. 22, pp. $363-420$.

McArthur, J. M., Donovan, D. T., Thirlwall, M. F., Fouke, B. W., and Mattey, D., 2000, Strontium isotope profile of the early Toarcian (Jurassic) oceanic anoxic event, the duration of ammonite biozones, and belemnite palaeotemperatures: Earth and Planetary Science Letters, v. 179, pp. 269 - 285.

McArthur, J. M., Howarth, R. J., and Bailey, T. R., 2001, Strontium isotope stratigraphy: LOWESS Version 3: Best fit to the marine Sr isotope curve for 0 - $509 \mathrm{Ma}$ and accompanying look-up table for deriving numerical age: Journal of Geology, v. 109, no.2, pp. $155-170$.

McArthur, J. M., and Howarth, R. J., 2004, Strontium isotope stratigraphy, in, Ogg, J. G., and Smith, A. G., eds, A Geological Time Scale 2004, Cambridge University Press, pp. 96 - 105.

McFadden, P. L., and Jones, D. L., 1981, The fold test in palaeomagnetism: Geophysical Journal of the Royal Astronomical Society, v. 67, no. 1, pp. 53 - 58.

McFadden, P. L., and McElhinny, M. W., 1990, Classification of the reversal test in palaeomagnetism: Geophysical International Journal, v. 103, pp. 725 - 729.

McFadden, P.L., and Reid, A., 1982, Analysis of paleomagnetic inclination data: Geophysical Journal of the Royal Astronomical Society, v. 69, pp. 307 - 319.

Meister, C., Schirolli, P., and J-L Dommergues, J.-L., 2006, Sinemurian to lowermost Toarcian of the Brescian Alps (Southern Alps, Italy): biostratigraphical framework and correlations: Volumina Jurassica, v. 4, pp. 184 - 185.

Metodiev, L., and Koleva-Rekalova, E., 2008, Stable isotope records $\left(\delta^{18} \mathrm{O}\right.$ and $\left.\delta^{13} \mathrm{C}\right)$ of Lower-Middle Jurassic belemnites from the Western Balkan mountains (Bulgaria): Palaeoenvironmental application: Applied geochemistry, v. 23, pp. 2845 - 2856.

Mouterde, R., 1955, Le Lias de Peniche. Comunicações dos Serviços Geológicos de Portugal, v. 36, pp. 87 - 115.

Mouterde, R., 1967, Le Lias du Portugal. Vue d'ensemble et divisions en zones. Comunicações dos Serviços Geológicos de Portugal, v. 52 , pp. $209-226$.

Ogg, J. G., 1995, Magnetic Polarity Time Scale of the Phanerozoic, in Global Physics. A Handbook of physical Constants: AGU Reference Shelf, v. 1, pp. 240 - 270.

Ogg, J. G., 2004. The Jurassic Period, in Grandstein, F., Ogg, J. G., and Smith, A., eds, A Geologic Time Scale 2004. Cambridge 
University. Press, United Kingdom, pp. 307 - 343.

Osete, M. L., Gialanella P. R., Gómez, J. J., Villalaín J. J., Goy A., and Heller, F., 2007, Magnetostratigraphy of Early - Middle Toarcian expanded sections from the Iberian Range (central Spain): Earth and Planetary Science Letters, v. 259, pp. 319 332.

Osete, M. L., Gómez, J. J., Pavón-Carrasco, F. J., Villalaín J. J., Palencia, A., Ruiz-Martínez, V. C. and Heller, F., The evolution of Iberia during the Jurassic from palaeomagnetic data: Tectonophysics, in press.

Page, K., 2003, The Lower Jurassic of Europe: Its subdivision and correlation, in Ineson, J. R., and Surlyk, F., eds, The Jurassic of Denmark and Greenland: Geological Survey Denmark and Greenland Bulletin, v. 1, pp. 23 - 59.

Palencia-Ortas, A., 2004, Estudio paleomagnético de rocas de edad jurásica de la Península Ibérica y del Norte de Marruecos. Ph. D. Thesis, Univ. Complutense Madrid, 230 pp. Madrid.

Rosales, I., Quesada, S., and Robles, S., 2004, Paleotemperature variations of Early Jurassic seawater recorded in geochemical trends of belemnites from the Basque-Cantabrian basin, northern Spain: Palaeogeography, Palaeoclimatology, Palaeoecology, v. 203 , pp. $253-275$.

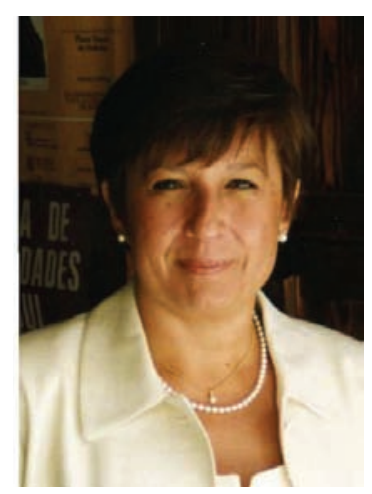

María José Comas-Rengifo is Full Professor of Palaeontology in the University Complutense of Madrid. She teaches Invertebrate Palaeontology at the Paleontology Department of the Faculty of Geological Sciences. She was Vice-dean of Research and Postgraduate and Doctorate studies of Faculty of Geological Sciences of UCM. Her research has concentrated on ammonite and brachiopod taxonomy, biostratigraphy and biocronology of the Sinemurian and Pliensbachian. She has been member of the Pliensbachian Working Group of the Subcommission on Jurassic Stratigraphy of the ICS since 1987.

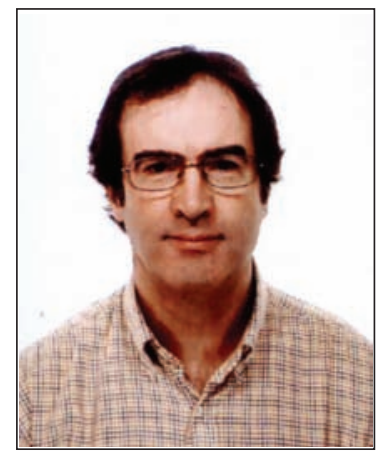

Juan J. Gómez obtained his degree in Geology in 1970 and completed his $\mathrm{PhD}$ in 1978 on the sedimentology of the Jurassic carbonates of the Iberian Range, in the University Complutense of Madrid (UCM). In 1987 he obtained a position of Professor in the Department of Stratigraphy of the UCM. His current research is focused on the links between climate changes and biotic crises and mass extinctions.
Ruiz, V., Lendínez, A., and Gabaldón, V., 1986, Geological map of Belchite: Instituto Tecnológico y Geominero de España, Sheet 440, scale 1:50.000.

Sælen, G., Doyle, P., and Talbot, M. R., 1996, Stable-Isotope Analyses of Belemnite Rostra from the Whitby Mudstone Fm., England: Surface Water Conditions During Deposition of a Marine Black Shale: Palaios, v. 11, pp. 97-117.

Schouten, S., van Kaam-Peters, H. M. E., Rijpstra, W. I. C., Schoell, M., and Sinninghe Damste, J. S., 2000, Effects on an oceanic anoxic event on the stable carbon isotopic composition of Early Toarcian carbon: American Journal of Science, v. 300, pp. 1 - 22.

Sequeiros, L., Cólera, I., Valenzuela, R., and Sánchez, I., 1978, Bioestratigrafía del Jurásico (Lias y Dogger) en el sector BelchiteAlmonacid de la Cuba (prov. de Zaragoza, Cordillera Ibérica): Estudios Geológicos, v. 34, pp. 293 - 298.

Suan, G., Mattioli, E., Pittet, B., Maillot, S., and Lécuyer, C., 2008, Evidence for major environmental perturbation prior to and during the Toarcian (Early Jurassic) Oceanic Anoxic Event from the Lusitanian Basin, Portugal: Paleoceanography, v. 23, PA 1202. doi: 10.1029/2007PA001459.

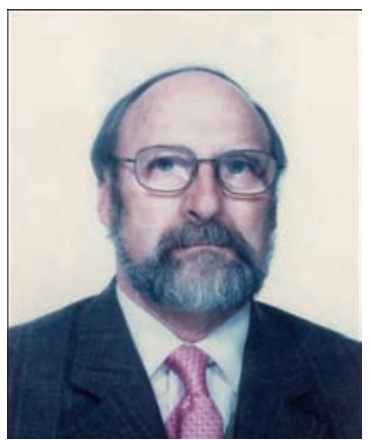

Antonio Goy is Professor of Palaeontology at the University Complutense of Madrid. For twenty years he was Head of the Palaeontological Department of this University. Besides he has been President of the Spanish Society of Palaeontology, Spanish Mesozoic Group, and the Royal Society of Natural History. His research has been mainly focused on Lower Jurassic and Aalenian ammonite taxonomy, biostratigraphy and sequence stratigraphy. He has been member of the Toarcian Working Group of the Subcommission on Jurassic Stratigraphy of the ICS since 1987. From 1987 to 1994 he was Chairman of the Aalenian Working Group. 